Exploring Information Literacy in Secondary Schools in Hong Kong: A Case

\title{
Study
}

\author{
van Aalst, J., Fung, A. W. H., Li, M. S. M., \& Wong, A. P. W.
}

Paper provided via HKU Scholars Hub

Please cite as follows:

van Aalst, J., Fung, A. W. H., Li, M. S. M., \& Wong, A. P. W. (2007). Exploring

information literacy in secondary schools in Hong Kong: a case study. Library \& Information Science Research, 29, 533-552.

Corresponding author: J. van Aalst, Faculty of Education, The University of Hong Kong; email: vanaalst@hku.hk 


\begin{abstract}
Current curriculum reforms in Hong Kong emphasize learning how to learn and project-based learning; the most recent reform introduces "Liberal Studies" as a mandatory school subject in senior secondary school. This article reports an exploratory case study of the Information Searching Process (ISP) in the context of these developments. Participants were 18 Form 6 (Grade 12) students, who completed a 5-week inquiry project in small groups, as part of a Liberal Studies course. Students were asked to complete a questionnaire, and keep a search log and diary; several students were also interviewed. The research questions examined the sources of information used by students, students' cognitive and emotional experience during the ISP, and communication within the collaborative groups. Findings indicated that Internet-based sources were predominant but that most students had difficulty completing the ISP. It is argued that work is needed to help students develop an epistemology in which the meaning of information is contextual and the process of interpreting information an effortful activity. Such work seems important if collaborative inquiry projects in Liberal Studies are to lead to deep learning.
\end{abstract}

KEY WORDS: Information Search Process, Liberal Studies, Learning to Learn, Project Learning

RUNNING HEAD: Collaborative information searching 


\section{Exploring Information Literacy in Secondary Schools in Hong Kong: A Case Study}

\section{INTRODUCTION}

Responding to accumulating evidence from education research about the learning process (Bransford, Brown, \& Cocking, 1999; Sawyer, 2006) and increased need for people who are prepared for directing their own learning as well as for teamwork, the Hong Kong government has introduced a series of education reforms. In 2000 it launched a "Learning to Learn" reform (Curriculum Development Council [CDC], 2000) and in a more recent reform it is introducing "Liberal Studies" as a mandatory subject in senior secondary schools (CDC \& HKEA, 2004). Like curriculum frameworks introduced elsewhere (e.g., National Council of Teachers of Mathematics [NCTM], 2000; National Research Council [NRC], 1996), these reforms emphasize inquiry, especially through projects in which students collaborate to investigate open-ended problems of current interest to society.

In the context of such reforms, developing information literacy in students has gained new importance. First, while the information search process (ISP) has been researched extensively in North-America and Europe, it has been researched less in Asian countries. What is the nature of Hong Kong students' cognitive and emotional experience of the ISP? Are students adequately prepared to conduct searches that are useful for their projects? Such questions are important because with the rise of the internet the availability of information to students has increased dramatically; although the potential for projects which use relevant and up to date information is considerable it is not clear whether Hong Kong students will be able to take advantage of it. Second, 
although collaboration is emphasized in current educational perspectives, the ISP has received little research attention in collaborative settings (Hyldegård, 2006). How do Hong Kong students work together on a collaborative ISP? Third, how students think about the ISP is also important. Education culture in Hong Kong is strongly focused on competition and assessment (Biggs, 1996), and this frequently leads to lessons that are highly structured, in contrast with more emergent lesson designs that build on students' interest and prior knowledge. While the ISP could teach students epistemological points about inquiry, for example that problems are initially ill-structured and that an inquiry gradually gains focus (Ruthven, Hennessy, \& Deaney, 2005), Hong Kong students may be relatively intolerant of ambiguity. Research is needed to examine Hong Kong students' experience of and thinking about the ISP, so that teachers may know how best to support students in conducting collaborative projects. It is proposed that without such support, proposals for increased emphasis on student-directed and collaborative inquiry are likely to have limited success. Perhaps even more important, an opportunity to help students develop a more sophisticated epistemology could be lost.

This article reports an exploratory case study of the ISP by Form 6 (Grade 12) students taking a Liberal Studies at a Hong Kong secondary school. The goal of the study was to explore the implications of Hong Kong's education reforms for the development of information literacy, focusing on students' cognitive and emotional experience of the ISP and their thinking about the ISP as important components of information literacy. As collaboration is emphasized in many contemporary perspectives on learning (Palincsar, 1998; Sawyer, 2006), the "case" involved collaborative inquiry in small groups. Thus the study responds to Hyldegård's (2006) call for more research on the ISP in collaborative 
settings. The study examined the information sources used by students, students' cognitive and emotional experiences of the ISP, and communication patterns among group members during the ISP. As an exploratory case study, the study is intended to elucidate research questions (Yin, 1993) and opportunities for the development of information literacy. These are outlined in the discussion section.

\section{LITERATURE REVIEW}

\section{Recent Educational Reforms in Hong Kong}

Education researchers have made many advances in their understanding of learning in the last 30 years. Among the most well known findings is that traditional teaching, in which the teacher explains and the students attempt to absorb what is explained, is rather ineffective. Many studies have shown that students do not gain deep knowledge that way but hold on to their own ideas (e.g., McDermott, 1984; Driver \& Easley, 1978). Other studies have shown that learning produced in this so-called "transmission mode" does not transfer well from one learning context to another (Perkins \& Salomon, 1989); such studies have revealed the importance of the nature of the learning context for both enabling learning and recalling what has been learned (Brown, Collins, \& Duguid, 1989; Hutchins, 1995; Lave \& Wenger, 1991). Numerous researchers have responded by developing and testing educational perspectives that promote deep learning, which includes not only ability to recall information and ideas, but also ability to see assumptions behind assertions, relationships among ideas, and the range of uses of ideas (Brown \& Campione, 1994; Kolodner et al., 2003; Linn \& Hsi, 2000; White \& Fredericksen, 1998). Common among many of these perspectives is that students need to interpret new information in light of their current beliefs and what they believe to be the 
current state of knowledge about a topic; students often learn by means of inquiry into problems that are likely to be personally relevant (Linn \& Hsi, 2000). Student inquiry into such problems is prominent in several curriculum frameworks in the U.S., most notably in standards for mathematics and science learning (NCTM, 2000; NRC, 1996). Studies involving student inquiry have also revealed important relationships between understanding and students' insight into their own learning (e.g., Baird, 1986). White and Fredericksen (1998) showed that students of below average achievement can benefit even more from tasks in which they reflect on the inquiry process than students above average academic achievement. Some studies suggest that students of widely varying achievement levels are able to control their learning process to a degree not thought possible at the start of the 1980s. We suggest there are good reasons to expect that deep learning, with a higher degree of control over the learning process than has so far been the norm, is possible for the majority of students (Bransford et al., 1999; White \& Fredericksen, 1998; Zohar \& Dori, 2003).

\section{Learning to Learn and Liberal Studies}

In the context of these developments and changing learning needs, the Hong Kong government conducted an extensive review of the school curriculum in 1999 and initiated major curriculum reforms for improving the quality of schooling. The first major reform effort, in a document entitled "Learning to Learn" (CDC, 2000), illustrates how the reform is based on a set of aims for education in the 21 st century:

To cope with the challenges of the 21 st century, education in Hong Kong must keep abreast of global trends ... The school curriculum, apart from helping students to acquire the necessary knowledge, should also help the younger 
generation to develop a global outlook, to learn how to learn, and to master life-long skills that can be used outside schools. (CDC, 2000, p. 1)

This reform initiative was followed in 2004 by a proposal that provides further evidence of shifts toward a new learning paradigm. In addition to other structural changes, a significant change is the introduction of a required subject called "Liberal Studies" in the new senior secondary school curriculum. The document introduces Liberal Studies as follows:

Liberal Studies adopts an issue-enquiry approach which helps liberate minds of students by having students study a wide range of issues and encouraging them to find out information themselves and develop their own opinions ... Students are encouraged to draw knowledge from different disciplines in the analyses of the issues, and to develop their own views, construct personal knowledge, and become critical thinkers. (CDC \& HKEA, 2004, p. 57)

\section{Key Tasks}

In order to help students develop independent learning capabilities, the Hong Kong government recommended four "Key Tasks" across the curriculum: Moral and Civic Education, Reading to Learn, Project-Based Learning, and Information Technology for Interactive Learning (CDC, 2000). These four key tasks are inter-connected. A focus on reading to learn helps students to do better in project-based learning, which involves searching and reading different kinds of materials. Similarly, project-based learning requires students to read widely for information, develop critical thinking, and construct personal knowledge and analysis. Schools can use any of these key tasks as an entry point to strengthen students' independent learning capabilities and help them ultimately 
to achieve the objectives of in all four key tasks.

\section{Liberal Studies and Project-Based Learning}

Following up on the learning to learn reform, Hong Kong is implementing a reform of the academic structure for senior secondary education and higher education in 2009; all Hong Kong students will from then receive three years of senior secondary education (instead of four), ending at Form 6 (Grade 12). In the new academic structure, Liberal Studies will be one of four core subjects, together with Chinese, English and Mathematics. Liberal Studies will include an independent study as part of its assessment. The instructional time devoted to the independent study will be 90 hours which is one-third of the total instructional time for Liberal Studies (CDC \& HKEA, 2004). In addition, whereas in the past many students left school after the Hong Kong General Certificate of Education Examination (HKCEE) in Grade 11 (Biggs, 1996), such students will in the new structure need to complete Grade 12 . Therefore, although some students have in the past completed independent projects in Grades 12 and 13, it will now become an important learning task for all secondary school students.

\section{Project Learning and Information Literacy}

As project learning will be an important part of Hong Kong students' learning experience, deeper understanding of their project learning process is needed. During project learning, students need to learn how to select a topic, to form a focus, to gather and evaluate information, and how to present the product. All of these relate to information literacy.

Definitions of information literacy usually focus on the person who is information literate rather than on the concept itself; Zurkowski (1974) referred to the 
information literate person as one trained in the application of information to one's work. More recent definitions link information literacy to lifelong learning. The 2003 Prague Declaration stated that information literacy "encompasses knowledge of one's information needs and the ability to identify, locate, evaluate, organize and effectively use information to address issues or problems at hand, is a prerequisite for participating effectively in the information society, and is part of the basic human right of life long learning” (quoted in Webber \& Johnston, n.d., ๆ11). A draft paper by the Hong Kong government argues that information literacy for the 21 st century includes ability to interpret information and develop new concepts (CDC, 2006). The definition used in this paper encompasses the Prague declaration and the Hong Kong definition, but adds a requirement of understanding of the epistemological nature of information-specifically that problems are initially lack precise definition and that information does not have context-independent meaning but needs to be interpreted in light of the specific context in which it is sought. According to Kuhlthau (2004, p. 11), one of the best ways to teach students information literacy is to engage them in authentic learning tasks such as may occur within student projects.

\section{Information Search Process (ISP)}

Information specialists are no longer locators but instructors or councilors who realize that information is subjective in nature and that they should help users create their own meanings of information. Todd (2003) identified three streams of research on information searching by children and adolescents. The first stream is Kuhlthau's (2004) Information Search Process (ISP) model that will be described in detail later. The second stream is "searching or surfing the World Wide Web" focusing on the characteristics of 
children and adolescents' information seeking on the Internet. The third steam is "everyday information seeking" focusing on adolescents' information seeking in daily life contexts. The need to develop learners' information and critical literacy is a consistent theme in this stream.

Large and Beheshti's (2000) study of Grade 6 students' experience of searching the Web for school project belong to the second stream. In this study students adopted a variety of strategies to seek information to complete school tasks, and some primary students still regarded printed materials as chief source of information for school projects. However, our informal observations of our own students suggested that our students rely on the World Wide Web as the main source of information, in everyday life and for school projects. We wanted to explore whether our observations were correct by case study.

Besides sources of information, we think that a deeper investigation into students' cognitive and affective experiences is important. Kuhlthau's ISP model can provide a useful framework to explore students' information seeking process. Kuhlthau's model is described next.

\section{Kuhlthau's ISP model}

The ISP model developed by Kuthlthau (2004) takes into account the information seeker's emotional, cognitive and physical experience at different stages of the process. The model describes the thoughts, actions and feelings commonly experienced by the information seekers in an inquiry process. According to Kuhlthau, there are six stages in the information seeking process: task initiation, topic selection, pre-focus exploration, 
focus formulation, information collection, and search closure. The detail descriptions of these six stages are as follows:

Stage 1: Task initiation: While preparing to select a topic, there are feelings of uncertainty. Students will have to recognize the need for information. Alternative possible general topics are selected. Students will talk with others and they will browse the library collection.

Stage 2: Topic selection: Students need to identify general topics. Although uncertainty still exists, students often feel optimism after they have selected the topic. Students choose what to pursue in response to the initiating question by considering what they already know and what they want and need to find out.

Stage 3: Pre-focus exploration: Students explore the initiating questions and develop their own questions that arise as they begin to learn about the subject. Students commonly come across information that is inconsistent and incompatible with what they already know and what they expected to find out. As a result, this stage is full of feelings of confusion, uncertainty and doubt.

Stage 4: Focus formulation: Students become aware of the various dimensions and issues of the question and begin to form their own focus of the subject under study. It is the turning point of the search process when uncertainty diminishes and confidence increases. Focuses become clear and can go to the next stage.

Stage 5: Information collection: Students gather information that supports the focus they have formed. As a result, their confidence and interest increase. They may request specific resources from the librarian and make a comprehensive search. 
Stage 6: Search closure: During the last stage of the ISP, students share what they have learned with the others. Before the presentation, there may be actions involving a summary search to recheck information that may have been initially overlooked. Eventually, there will be a conclusion; students reflect on what they have learnt to discover what might be improved.

Figure 1 summarizes Kuhlthau's ISP model. According to the model, the thoughts of information searchers should change from ambiguity to specificity; at the same time, searchers' feelings change from uncertain in the initial stage to optimistic once they have selected a topic; however, students feel confused during the pre-focus exploration stage. Students feel a sense of clarity after they have formulated focus. During the information collection stage, students feel a sense of direction and confidence. Finally, during the search closure stage, they will feel relief. However, if students do not succeed in formulating a clear focus, they will experience frustration. Searchers should also experience an increase their interests in the topic after the focus formation stage.

[Insert figure 1 about here.]

\section{Collaborative ISP}

Kuhlthau's model is the basis of many studies of information seeking. However, as Hyldegård (2006) has argued, one of the shortcomings of these studies is the neglect of collaborative nature of information searching. Hyldegård examined social aspects of searching for, sharing, and generating information, and asked whether there were differences in the ISP of groups, compared with individuals. Specifically, she examined the information searching of five graduate students in a qualitative study, and found that although group members demonstrated similar cognitive experiences as individuals in 
the ISP model, they did not necessarily experience the emotional "turning point" during the process. In other words, students may not have a sense of relief at the sixth stage of the ISP. Hyldegård argued that contextual and social factors affect the group ISP, and called for further research on collaborative and social factors relating to group members' information searching. To our knowledge, no studies exist that have explored Hyldegård's questions with secondary school students.

\section{Focus of the Study}

As stated earlier, the goal of the study was to explore the implications of education reforms like those currently being implemented in Hong Kong for the development of information literacy. There are few studies of information literacy of secondary school students in Hong Kong, and none that focus on the ISP in collaborative contexts. The following four research questions were explored:

1. What kind of information sources do Hong Kong students use in project learning?

2. What are the cognitive and emotional experiences of Hong Kong students during information search process?

3. What factors affects students' collaborative information seeking in project learning?

\section{METHODOLOGY}

\section{Research Team and Orientation}

The study falls within a teacher as researcher perspective in which a team of researchers collaborate, often with a faculty advisor, to study a problem important to their practice (Murray \& Lawrence, 2000; Stenhouse, 1975). The research team consisted of three school librarians and one faculty advisor; one of the school librarians taught a 
class of Form 6 students taking Liberal Studies ("the teacher" hereafter). The three school librarians met regularly and collaborated at all stages of the research.

Research methods commonly used for research on adolescents' information searching include questionnaires, records of computer keystrokes, observation, focus groups, interviewing, think aloud protocols, students' journals and diaries, students' timelines, and students' work and assignment materials; frequently combinations of methods are employed (Shenton, 2004). In this study the main data sources were questionnaires, search logs, and search diaries; a sample of students were interviewed to probe more deeply into issues identified by the other data sources. These multiple data sources made triangulation of our inferences possible (Creswell \& Miller, 2000). Individual as well as collaborative aspects of the ISP were investigated.

\section{Participants}

The participants were 18 Form 6 (Grade 12) students (5 male and 13 female) taking a Liberal Studies course at a secondary school in Hong Kong. In Hong Kong, schools are placed in three bands based on students' performance on government exams, and this school was in the highest band (Band 1) at the time of the study. All students had previously completed an inquiry project in Form 3. Prior to the start of the inquiry project, the teacher explained that she wished to conduct research on the students' information seeking, the procedures she intended to follow in this research, and that participation in the research was voluntary. All 18 students agreed to participate in the study. Most students reported they had experiences seeking information for individual as well as group-based project assignments; seven (38.9\%) had at least four years 
experience and 11 students $(61.1 \%)$ had at least five years of general experience using the Internet.

\section{Procedure}

At the beginning of the school year, the students had a lesson in the library on information searching focusing on the use of the school's Online Public Access Catalogue (OPAC), the use of Boolean operators, and the stages of the Kuhlthau ISP model. Students were also introduced to WiseNews, an electronic newspaper database. In the Liberal Studies course, students were taught social policy relating societal issues in preparation for the projects. However, as the project assignment was designed to meet a curriculum requirement of self-directed investigation, the teacher only explained the project goals and assessment. Students were then divided into groups and each group was assigned a project; there were six groups and one student who worked alone. The teacher assigned the group members according to students' research interests. Students were asked to select a topic from a broad study area (e.g. education, economics, politics etc.) and form their own focus, then search information to support their focus, and finally report their research to their classmates in a presentation. The duration of the inquiry project was five weeks (April to May, 2006).

\section{Data Sources}

Questionnaire: At the end of the inquiry project, all participants completed the questionnaire (see Appendix). The questionnaire probed their students' experience with the ISP and was a modified version of that developed by Hyldegård (2006); it consisted of 19 questions. Modifications consisted of the addition of items relating to difficulties encountered during the ISP, the role of the teacher during the ISP, and communication 
within collaborative groups; the items were presented in English and Chinese (side-by-side), as is customary in Hong Kong.

Search Log and Search Diary: Each student was asked to fill in the Search Log and Search Diary after each information search on the topic. The search log was a modified version of Kuhlthau's (2004, p. 32) search log. The students were asked to record what tools they used, the usefulness of the information, and their feelings during the information-seeking process. Making entries in the search log and dairy provides students a way to record and reflect on the success of the search. A sample search diary used by the teacher to demonstrate how to fill one out is shown in Figure 2.

Interviews: After analysis of these data, the teacher selected one reasonably articulate and confident student from each group for a follow-up interview. Unfortunately, due to scheduling difficulties only three students could be interviewed. The purpose of the interviews was to gain deeper insight into the main patterns in the other data. For example, students were asked to elaborate on questionnaire responses to examine the reasons for choosing one type of information over another or why students felt a certain way during the ISP. Students were interviewed by the teacher in the school library to create a familiar and non-threatening setting for the interviews. The interviews were transcribed verbatim by one team member and the transcripts checked by the teacher. Despite the small sample, the interviews were useful for verifying researcher interpretations based on other data sources and yielded additional insight into the students' experience of the ISP.

[Insert Figure 2 about here]

Analysis 
Techniques for analyzing questionnaires used in teacher research were employed. First, quantitative responses to the questionnaire items were summarized by one team member and then checked by other team members. The team then discussed the results to develop preliminary answers to the research questions. These were then checked and elaborated by examining the other data sources. These methods fall within recommendations by Wildemuth (2002) for conducting research on young people's information-seeking behavior, and allow for triangulation of inferences between several data sources as recommended by many researchers (Creswell \& Miller, 2000). Information searching was examined at both individual and group levels.

\section{RESULTS}

All 18 students handed in search diaries and 17 handed in search logs. All students could briefly describe their research topic. From their descriptions on their project topic, the teacher concluded that 11 students (61.1\%) could articulate clear focus of their research topic; 7 students (38.9\%) said on the questionnaires that they had some knowledge about the topic beforehand, while 11 students (61.1\%) said that they had little knowledge about the topic beforehand.

\section{Sources of Information}

The first research question was: "What kind of information sources Hong Kong students use in project learning?" The questionnaire asked students to rate the importance of the information sources they had used for the project from 1 (low) to 5 (high). Descriptive statistics are shown in Table 1. (The left column is based on 14 questionnaires as four students ignored the instruction to rate only sources they had used.) The categories were not completely independent but students appeared to have little 
difficulty completing the questionnaire item. Nearly all 14 students included in this analysis reported using web pages, WiseNews, and group members at least once; by comparison the use of material from the library and other printed materials was much less frequent (4 students and 7 students respectively). Regarding importance of the information sources, students appeared to have a clear preference for web-based materials, rating web pages highest (4.22) followed by WiseNews (3.84), ahead of group members (3.35) and the teacher (3.23). While moderate importance of the teacher as information source is expected in a student-directed inquiry project, one would expect students in the group to be regarded as important sources of information in a collaborative project. Students rated library materials (2.88) and the OPAC (2.75) as moderately unimportant and printed materials (1.64) as least important.

\section{[Insert Table 1 about here]}

This general picture was confirmed by the students' search logs. There were 82 entries in total; 39 of these (47.6\%) referred to web resources and 20 (24\%) to WiseNews; only 12 entries $(14.6 \%)$ referred to school library resources. The three students interviewed all said they sought information solely from the Internet. Student $2 \mathrm{C}$ explained why he used the Web as the chief sources of information: "The Web sources are very convenient to find. We can use the search functions. There [is] too much content in books and I don't want to read them." Student 6C agreed with Student 2C: "The Web is more convenient. We have remedial classes after school. The libraries have already closed after the classes. I usually do my searching from 9:00 pm to 11:00 pm. It is not possible for me to search other sources." Student 1B had another reason to use the Web: "We can find the most updated information from the Web. Our research topic is a current 
issue. We could not find information from other sources." When asked further why they did not use library materials, all students interviewed said that they did not know how to search materials in school library except browsing. Two students said they had never heard of the Online Public Access Catalogue (OPAC) of school library (Student 1B \& 6C). Student $2 \mathrm{C}$ said that he knew it and tried to find books from the OPAC, but when he could not find relevant information from OPAC he would search by browsing.

Cognitive and Emotional Experiences

The second research question was: "What are the cognitive and emotional experiences of Hong Kong students during information search process?” The researchers sought to explore if students went through the six stages of ISP. According to Kuhlthau (2004), there are three indicators that can be used to measure whether students have gone through the six stages of ISP: thoughts, feelings, and actions. Since in this study it was not possible to observe students' actions directly we focused on the first two indicators using self-reported data.

\section{Cognitive experience.}

A clear focus is an important indicator of whether students complete the six stages of the ISP; focus formation is a "turning-point" in Kuhlthau's ISP model (Hyldegård, 2006; Kuhlthau, 2004). Once students formulate a focus, they will experience feelings of clarity and confidence. According to questionnaire responses, students regarded focus formation the most difficult part of the search process. 11 students (61.1\%) said that they found focus formation was most difficult or quite difficult; only 4 students (22.2\%) said that focus formation was less or least difficult. Further, only 5 students $(27.7 \%)$ said their understanding of the focus of the project was clear at the 
end of their information search. Eight students (44.4\%) said they disagreed or agreed a little that their understanding of the focus of the project was clear. Student $1 \mathrm{~A}$ wrote on the questionnaire: "The main problem was I did not know what [was] the focus." From teacher's assessment and students' presentations, we found that some groups could not formulate a clear focus till the end of the search process. That means they did not complete the six stages of ISP model.

Some students appeared to be overwhelmed by the large quantity of information yielded by their searches. Student 1A wrote in his search diary: "Have found too much information, and it is hard to digest them at once. It caused me [a] headache." Student 1B wrote in his search diary: "Continued to search information but found that most information was not relevant." Student 1C made similar comments in her diary: "The contents of these articles are similar; it's hard to find new information". Student 5B expressed similar views on her questionnaire: "It's very hard to find really relevant information via the Internet." Nevertheless, despite evidence of struggling with the cognitive demand involved in searching, there was evidence that some students were able to complete all six of the stages. Student 1B described his search experiences vividly in the interview, suggesting that interest also plays an important role in managing the search process:

At first I felt uninterested but quite bothered with the assignment. Oh, another assignment has to be completed. I was more bothered when our group began selecting a topic. We could not select a topic for a long time. I began increasing my awareness of current affairs to see if I could have any new ideas. I found that my search topic is related to daily lives. My interest increased and felt a bit 
excited. Finally, we have selected a topic. I have strong motivation to find relevant information. I wanted to complete our assignment as soon as possible. However, I was bothered again. Too much information, I didn't know how to deal with them. At last we selected relevant information for our assignment. I felt happy. I enjoyed working with my group members. I felt satisfied.

From the interviews and search diaries we also found that students thought discussions with their teacher helped them formulating a clear focus. Student 5A described her experience on her questionnaire: "I did not know how to define the topic and how to formulate a research focus. However, after discussion with teacher and group members, I have clearer ideas."

Emotional experience.

Questions 16 and 17 of the questionnaire asked students how they felt at the beginning and the end of the project. Most students said they felt uncertain (44.4\%) and confused (55.6\%) at the beginning; four students (22.2\%) said they felt excited and two (11.1\%) relieved. After the search process only one student (5.5\%) reported feeling more certain after the search process, and seven students (38.9\%) reported feeling frustrated. None of the students expressed excitement at the end of search (see Figure 3). Despite these difficulties, some students reported positive feelings at the end of information-seeking process. For example, student 2B wrote on her questionnaire: "I feel so good right now. I have done an interested topic, and I enjoy working with my group members."

[Insert Figure 3 about here]

Collaborative Information Seeking 
The third research question was: "What factors affect students' collaborative information-seeking in project learning?" The student who worked alone is excluded from the analysis. Findings are reported regarding how students communicated to get the ISP done, followed by data on motivation and the success of the ISP.

Students used various ways to communicate with their group members. MSN/ICQ, telephone and meeting were the most popular communication methods. Group 2 and 3 used more meetings to communicate with group members; Groups 4, 5 and 6 used more MSN/ICQ than other groups (see Table 2). Thirteen students said that they were in contact with group members weekly; four students said they contacted their group members several times in a week. Students IB and 2C explained that meetings were more effective for communication because "Communications through MSN/ICQ usually are very short. You have to type in MSN/ICQ, sometime you don't know how to type [in Chinese] and then you won't mention it. But in meetings, you can express whatever you want to say and it is much longer in meeting." Nevertheless, these students still thought that MSN/ICQ is an important communication method because it is convenient. They said that once they had selected a topic and formed a focus, it would be better not to have meetings because so many ideas will be raised. From students' comments, we can see that at the beginning of a group project learning, meetings may be important to the success of group project learning experiences.

[Insert Table 2 about here]

To explore intra- and inter-group differences in experience of the ISP, agreement scores are shown in Table 3 for two statements on the questionnaire: "My understanding of the focus of the project is clear," and (b) "I am motivated to do the project." For both 
statements, scores range form 1 to 5, a 5 indicating high agreement. Hyldegård (2006) suggested that intra-group differences in personal variables such as motivation and mood can affect performance on a collaborative ISP, especially the resolution of uncertainty. As she reviewed, research on group dynamics has shown that the resolution of uncertainty within groups is a main goal of intra-group communication (Sorrentino \& Roney, 2000) and important to developing a sense of belonging to a group. Hyldegård found substantial intra-group differences of at least two points on a 5-point scale, and related these differences to difficulties in reaching consensus about the focus and approach to the project and to the fact that the participants did not know each other well at the start of the project. In the present study, the teacher also assessed the success of the collaborative ISP at the end of the project, when the groups made their presentations. She gave a rating from 1 to 5 for the ISP based on the extent to which a focus was achieved, her impression of students' satisfaction with the search and its usefulness to the inquiry project. Although this assessment mixes cognitive and affective aspects of the ISP, it is suggested this assessment does provide a general indication of the success of the ISP. These ratings are also shown in Table 3.

As the table shows, in two groups there was considerable intra-group variation for understanding the focus of the search (Groups 4 and 6). The intra-group variation for the motivation was small, and much smaller than in Hyldegård's study. The inter-group variation for both variables was more substantial. Generally, small intra-group variation and high scores for understanding the focus led to better searches, as measured by the teacher assessment. By comparison, the relationship between motivation scores and the teacher assessment was less clear. For example, while in Group 2 all students had high 
motivation scores and this was accompanied by a high teacher assessment, Group 4 received a low teacher assessment despite high motivation scores. Group 1 received a moderately high teacher assessment in spite of uniformly low motivation scores. Overall, the teacher assessment indicates that the ISPs of most groups left much room for improvement: only one group received a teacher assessment above a 3.

[Insert Table 3 about here.]

The Roles of Leaders in Collaborative ISP

Initially, the possible role of a group leader was not considered; however, students raised this issue when the teacher asked Student $1 \mathrm{~B}$ and $2 \mathrm{C}$ to share experiences that made their groups successful. They both said that their group's success was due to their (unassigned) leaders, and that they liked following their leader during the ISP. Both Groups 1 and 2, in effect, had leaders who were academically high-achieving. Student 2A, a high-achiever who was regarded by group members as their leader, reflected on her questionnaire: "I felt a bit interested [in] our topic, my interest increased while I collected more information, then I hoped I could know more about the topic.” The search logs and diaries for these groups suggest that all students were actively involved in the search, and they made the largest number of entries in their diaries. For example, the three students in Group 1 made 5, 5, and 2 entries in their diaries, and the students in Group 2 made 6, 4, and 4 . In addition, according to Table 3, the intra-group variation for understanding the focus was small. In contrast, Student $6 \mathrm{C}$, from the group receiving the lowest teacher assessment (Table 3), said: "We have no leader. [A high-achieving student] could be [our] leader. However, she's just too busy to work on our project.” In this group, the number of diary entries was consistently lower $(2,1,2$, and 3$)$, and the intra-group variation in 
understanding of the focus relatively high. These findings suggest that the main benefit of having a leader was to improve the collaborative process, contrary to fears that that in collaborative work the leader does most of the work (Colbeck, Campbell, Bjorklund, 2000). Although students may have had various group project experiences, some were more effective than others. All three students interviewed expressed their willingness to participate in group-projects again in the future. They all said that they learned much from discussions with their group members, and that peers could find additional relevant information for them.

\section{DISCUSSION}

As an exploratory study it is important to point out the limitations of the study. First, only one example of an inquiry project was investigated; the amount of information available for projects on different topics can be expected to vary, and students may also become better at the collaborative ISP with repeated practice from multiple inquiry projects. Second, the students had little instruction on the ISP; additional feedback on the collaborative ISP can also be expected to improve the results. Third, there were methodological problems that are common in practitioner oriented research. Despite these limitations, the study has analytic validity (Yin, 1993) in that its findings are similar to those from other case studies examining the ISP (Hyldegård, 2006; Prensky, 2001; Ruthven et al., 2005; Tabatabai \& Shore, 2005) and can be used to clarify problems. Below, four main findings and their implications are elaborated.

First, students considered web pages the most important information source for doing their projects, ahead of traditional library sources, the teacher, and paper sources obtained outside the library. Though this finding is contrary to Large and Beheshti's 
(2000) study it is no longer surprising. $61 \%$ of students reported having at least five years of experience with using the Internet; indeed, these students may be regarded as "digital natives" (Prensky, 2001), who consider digital information sources before paper information sources, contrary to many of their teachers, who Prensky regarded as "digital immigrants." Accordingly, it is unclear whether teachers are adequately prepared for supporting student projects with a substantial dependence on digital media such as web pages and instant messaging.

Second, while some students were able to complete the ISP, most experienced difficulties, especially with developing with coping with a large amount of information and developing a focus. This finding is especially important for the education reforms in Hong Kong, as the class was from an academically above-average (Band 1) school. The difficulties with completing the ISP in this study are likely to be more severe in classes drawn from an academically more diverse population, as will be the case after the reform takes full effect. Further, it is clear that the heavy use of web pages was an important contributing factor to students' difficulty in completing the ISP. The student comments quoted earlier indicate that students searched the Internet extensively, but that it was difficult to find relevant information. One student explained "I began increasing my awareness of current affairs to see if I could have any new ideas," after which the focus of the search improved. These results are consistent with a novice-expert comparison study of web searching, in which Tabatabai and Shore (2005) noted that experts, in addition to evaluating the relevance of search results, had greater knowledge about the target topic, maintained a positive attitude toward the search, and did not search excessively. 
Problems in obtaining relevant information from internet searches have led many teachers to vet internet sources and structure inquiry projects (e.g., Dodge, 1995; Linn \& Hsi, 2000). Such approaches focus students' attention on interpreting information (summarizing, synthesizing, and integrating it with prior knowledge) rather than locating it. However, as Ruthven et al. (2005) pointed out, "if the process of searching, including the discussion between pupils and the interaction with teachers which potentially surround it, can serve a developmental function not just an intermediate one, deepening understanding of subject matter and its epistemological dimension as well as locating contributory information, then the contribution of search activity assumes a wider significance" (p. 33, emphasis added). It is this "wider significance" that is envisaged by curriculum reforms emphasizing learning to learn and inquiry (CDC, 2000; NRC, 1996).

Although it has been noted before that much Internet content is not reviewed for quality (Dodge, 1995), students in this study had difficulty focusing their searches and dealing with the large amount of information yielded by their searches. Two facets of how these problems could be addressed are outlined. First, teaching could address these problems directly by helping students develop more effective searching strategies. In this, it is important to recognize that students already use a variety of methods that may serve them well for locating, sharing, and discussing information, such as instant messaging, bulletin boards, telephone calls, and face to face meetings; the use of such methods is clearly important to understanding the ISP for adolescents. According to this study, however, students need help dealing with the searching and evaluation of documents available on the Internet. Tabatabai and Shore (2005) recommend using clear criteria to evaluate sites, not excessively navigating, reflecting on strategies and monitoring 
progress, and approaching the search with a positive attitude. Clearly fostering the development of such strategies will support learning how to lean better than vetting internet documents, although a combination of the two methods is probably needed.

While developing more effective search strategies in students may to lead to better search outcomes and less student frustration with the ISP, a change in epistemological understanding of information, accompanied by greater tolerance of uncertainty, is also needed. Societal problems that may be the subject of projects in Liberal Studies are complex and initially ill-defined. For example, when students want to develop a position on whether stem cell research should be allowed in Hong Kong, it is not clear at the outset what the problem is. The actual problem emerges from what students already know in the subject area, current events and media coverage, the information students retrieve in their early searches, as well as their biases and interests; similar to scientific discourse, whether students work alone or collaborate, the problems they investigate are social constructions (Latour, 1987). Similarly, the documents students encounter are social constructions (e.g., some are intended to reach a wide audience and lack detail while others are intended for scientists and have undergone more rigorous review; some rapid communications result from intense interest in a recently elaborated problem). In short, it is proposed that students need to be able to interpret documents in terms of the social context in which they were produced and are to be used by them rather than the documents having context-independent meaning; ideally, students would see themselves as participating in a social and historical discourse aimed at knowledge production (Scardamalia \& Bereiter, 2006). Research on epistemological beliefs shows considerable epistemological development would be required in 
adolescents to achieve this (Hofer \& Pintrich, 1997; King \& Kitchener, 1994). However, a study by Whitmire (2003) suggests that such epistemological development can positively influence effectiveness of the ISP, and it is an essential part of the metacognitive development needed for learning how to learn (recent scholarship posits epistemological belief as part of metacognitive development, for a discussion see Pintrich, 2002).

Third, the groups used a variety of ways to communicate during the ISP; some groups used all three of email, instant messaging, and telephone to get their work done. This finding is interesting because it suggests that (a) different groups had difference preferences influencing how they collaborated and (b) that some of the communication media used were those students used in everyday life, such as instant messaging and telephone calls. Thus, to study how students accomplish the collaborative ISP during projects, it may be necessary to study communication in a variety of media, and not just the media that are provided by school for school work. (However, in this study no specific medium was provided for the project.)

Fourth, some groups spontaneously chose a group leader; groups which had a leader had more successful ISP, as measured by the teacher assessment. Indeed, having a leader seemed to have a greater impact on the ISP than motivation or intra-group differences in motivation. It is proposed that the natural emergence of group leaders is, in part, culturally mediated, as social arrangements in Hong Kong are often hierarchically organized (e.g., social positions within families are determined by birth order, in the workplace policies are set by senior staff members with less consultation than in the West, the tendencies of students not to question the authority of the teacher, and the 
existence of a two-level system by with politicians are elected). While these hierarchies are mostly accepted by Hong Kong citizens, it is educationally problematic if they also permeate school work. In contrast, in the West group work is not normally hierarchical; for example, in "cooperative learning" (Aronson, 1978) students are assigned different roles but there is no hierarchy among these. In addition, advocates of student-centered learning use social arrangements that are designed to counteract the hierarchy between teacher and student authority (Scardamalia \& Bereiter, 1991; Brown \& Campione, 1994); in "reciprocal teaching" students take turns to take the teacher roles in small groups (Palincsar \& Brown, 1984). When leaders do emerge in group work it is often because someone needs to take charge of the project when some students are unwilling to contribute; in such cases the leader does most of the work and there can be "free riders" (Colbeck et al., 2000). This kind of educational arrangement is inequitable, and clearly undermines goals to promote collaboration as part of a learning strategy. Though this kind of group work is also commonly found in Hong Kong, in the current study the leadership style used appeared to support collaboration and the ISP; if this interpretation is correct the use of leaders was clearly educationally beneficial. Further research is needed to elucidate the impact of the hierarchical structure of Hong Kong's society on collaborative work as part of ISPs and projects; it is suggested that the collaborative pedagogies from the West cannot just be implemented in Hong Kong, but that both the challenges and promises of collaboration among Hong Kong students are unique.

\section{CONCLUSION}

Current education reform in Hong Kong is of considerable interest because it builds on findings from decades of research on how people learn (Bransford et al., 1999; 
Sawyer, 2006) and international trends that emphasize inquiry projects (NCTM, 2000; NRC, 1996). Given the need for information in inquiry projects, success depends critically on developing information literacy in students and teachers. The findings of this study suggest that the importance of the Internet as a resource for projects has been underestimated; students preferred Internet sources over traditional sources and used communication tools like instant messaging to get their work done. As most teachers are not "digital natives," substantial learning by teachers is needed to become fluent in the use of internet-based technologies and to know how they can instructionally guide their use for projects. More specifically, teachers could help students develop better search strategies, as proposed by Tabatabai et al. (2005). However, focus on inquiry in school also provides an opportunity to foster more sophisticated epistemological understanding of information - that information is created and used in specific social contexts, does not have objective meaning, and, therefore, that considerable effort is needed to interpret it in the specific context of a student project. This kind of epistemological understanding is an important aspect of learning how to learn; the need for an effortful process to interpet information is one reason for promoting collaboration. In light of these points, it is suggested that the concept of information literacy needs to be extended to include epistemological understanding of information. Finally, it was suggested that another point that needs to be considered is the extent to which hierarchies, observed through the emergence of leadership roles, constrain and enable collaborative searching and project work. 


\section{REFERENCES}

Aronson, E. (1978). The jigsaw classroom. Beverly Hills, CA: Sage.

Baird, J. R. (1986). Improving learning through enhanced metacognition: A classroom study. European Journal of Science Education, 8, 263-282.

Biggs, J. (Ed.) (1996). Testing: To educate or to select? Education in Hong Kong at the crossroads. Hong Kong, SAR, China: Hong Kong Educational Publishing Co.

Black, P., \& Wiliam, D. (1998). Assessment and classroom learning. Assessment in Education: Principles, Policy, and Practice, 5, 7-74.

Bransford, J. D., Brown, A.L., \& Cocking, R. R. (1999). How people learn: Brain, mind, experience and school. Washington, DC: National Research Council.

Brown, A. L., \& Campione, J. C. (1994). Guided discovery in a community of learners. In K. McGilly (Ed.), Classroom lessons: Integrating cognitive theory and classroom practice (pp. 229-270). Cambridge, MA: MIT Press.

Brown, J. S., Collins, A., \& Duguid, P. (1989). Situated cognition and the culture of learning. Educational Researcher, 18(1), 32-42.

Colbeck, C.L., Campbell, S.E., \& Bjorklund, S.A. (2000). Grouping in the dark: What college students learn from group projects. The Journal of Higher Education, 71, 60-83.

Creswell, J. W., \& Miller, D. L. (2000). Determining validity in qualitative inquiry. Theory into Practice, 39 (3), 124-131.

Curriculum Development Council (2000, November). Learning to learn: The way forward incurriculum development. Hong Kong: Hong Kong Special Administrative Region of The People's Republic of China. 
Curriculum Development Council and the Hong Kong Examination and Assessment Authority (2004, October). Proposed core and elective subject frameworks for the new senior secondary curriculum. Hong Kong: Hong Kong Special Administrative Region of The People's Republic of China.

Curriculum Development Council (2006). Information Literacy for the 21st Century. Retrieved December 20, 2006, from http://www.emb.gov.hk/FileManager/EN/Content_4424/il_example james.pdf.

Dillenbourg, P. (1999). Introduction. What do you mean by 'collaborative learning'? In P. Dillenbourg (Ed.), Collaborative learning: Cognitive and computational approaches (pp. 1-19). Amsterdam, the Netherlands: Pergamon, Elsevier Science.

Dodge, B. (1995). WebQuests: A technique for Internet-based learning. Distance Educator, 1 (2), 10-13.

Driver, R., \& Easley, J. (1978). Pupils and paradigms: a review of literature related to concept development in adolescent science students. Studies in Science Education, $5,61-84$.

Hofer, B.K., \& Pintrich, P.R. (1997). The development of epistemological theories: Beliefs about knowledge and knowing and their relation to learning. Review of Educational Research, 67 (1), 88-140.

Hutchins, E. (1995). Cognition in the wild. Cambridge, MA: MIT Press.

Hyldegård, J. (2006). Collaborative information behavior-exploring Kuhlthau's Information Search Process model in a group-based educational setting. Information Processing \& Management. 42, 276-298. 
King, P. M., \& Kitchener, K. S. (1994). Developing reflective judgment: Understanding and promoting intellectual growth and critical thinking in adolescents and adults. San Francisco, CA: Jossey-Bass Publishers.

Kolodner, J. L., Camp, P. J., Crismond, D., Fasse, B., Gray, J., \& Holbrook, J., et al. (2003). Problem-based learning meets case-based reasoning in the middle-school science classroom: Putting learning by design into practice. The Journal of the Learning Sciences, 12, 495-547.

Kuhlthau, C.C. (2004). Inside the search process: Seeking meaning from the users perspective. Journal of the American Society for Information Science, 42, 361-371.

Kuhlthau, C.C. (2004). Seeking meaning: A process approach to library and information service,. 2nd edition. Westport, CT: Libraries Unlimited.

Latour, B. (1987). Science in action: How to follow scientists and engineers through society. Cambridge, MA: Harvard University Press

Large, A., \& Beheshti, J. (2000). The web as a classroom resource: reactions from the users. Journal of the American Society for information science, 51, 1069-1080.

Lave, J., \& Wenger, E. (1991). Situated learning: Legitimate peripheral participation. New York, NY: Cambridge University Press.

Linn, M. C., \& Hsi, S. (2000). Computers- teachers, peers: Science learning partners. Mahwah, NJ: Lawrence Erlbaum Associates.

McDermott, L.C. (1984). Research on conceptual understanding in mechanics. Physics Today, $38(\mathrm{x}), 1-10$.

Murray, L., \& Lawrence, B. (2000). Practitioner-based inquiry: Principles for postgraduate research. London, UK: Falmer Press. 
National Council of Teachers of Mathematics [NCTM] (2000). Principles and standards for school mathematics. Reston, VA: NCTM.

National Research Council [NRC] (1996). National science education standards. Washington, DC: National Academic Press.

Palincsar, A.S. (1998). Social constructivist perspectives on teaching and learning. Annual Review of Psychology, 49, 345-375.

Palincsar, A.S., \& Brown, A.L. (1984). Reciprocal teaching of comprehension-fostering and comprehension-monitoring strategies. Cognition and Instruction, 1, 117-175.

Perkins, D.N., \& Salomon, G. (1989). Are cognitive skills context bound? Educational Researcher, 18 (1), 16-25.

Pintrich, P.R. (2002). Conclusions. In B.K. Hofer \& P.R. Pintrich (Eds.), Personal epistemology: The psychology of beliefs about knowledge and knowing (pp. $387-414)$.

Prensky (2001). Digital natives, digital immigrants. On the Horizon, 9 (5), 1-6.

Ruthven, K., Hennessy, S., \& Deany, R. (2005). Incorporating Internet resources into classroom practice: pedagogical perspectives and strategies of secondary-school subject teachers. Computers \& Education, 44, 1-34.

Sawyer, R.K. (Ed.) (2006). The Cambridge handbook of the learning sciences. New York, NY: Cambridge University Press.

Scardamalia, M., \& Bereiter, C. (1991). Higher levels of agency for children in knowledge building: A challenge for the design of new knowledge media. The Journal of the Learning Sciences, 1, 37-68. 
Scardamalia, M., \& Bereiter, C. (2006). Knowledge building; Theory, pedagogy, and technology. In R.K. Sawyer (Ed.), The Cambridge handbook of the learning sciences (pp. 97-115). New York, NY: Cambridge University Press.

Shenton, A. K. (2004). Research into young people's information-seeking: perspectives and methods. Aslib Proceedings. Bradford: 56(4), 243-254.

Sorrentino, R.M., \& Roney, C.J.R. (2000). The uncertain mind: Individual differences in facing the unknown. Lillington, NC: Edwards Brothers.

Stenhouse, L. (1975). An introduction to curriculum research and development. Oxford, UK: Heinemann Educational.

Tabatabai, D., \& Shore, B. M. (2005). How experts and novices search the web. Library \& Information Science Research, 27, 222-248.

Todd, R. J. (2003). Theme section: adolescents of the information age: patterns of information seeking and use, and implications for information professionals. School Libraries Worldwide. 9(2), 27-46.

Webber, S., \& Johnston, W. (n.d.). Information literacy: definitions and models. Retrieved November 2, 2006 from http://dis.shef.ac.uk/literacy/definitions.htm . White, B. Y., \& Fredericksen, J. (1998). Inquiry, modeling, and metacognition: Making science accessible to all students. Cognition and Instruction, 16, 1-118.

Whitmire, E. (2003). Epistemological beliefs and the information-seeking behavior of undergraduates. Library \& Information Science Research, 25, 127-142.

Wildemuth, B. M. (2002). Effective methods for studying information seeking and use. Journal of the American Society for Information Science and technology. 53, $1218-1222$. 
Yin, R. (1993). Application of case study research. Thousand Oaks, CA: Sage Publications.

Zohar, A. \& Dori, Y.,J. (2003). Higher order thinking skills and low achieving students-are they mutually exclusive? Journal of the Learning Sciences, 12(2), $145-182$.

Zurkowski, P. G. (1974). The information service environment relationships and priorities. Washington, DC: National Commission on Libraries and Information Service. 
Table 1

Types of information used

Table 2

Intra-group communication modes (frequencies)

Table 3

Motivation and search performance

Figure 1

Kuhlthau's model of the Information Search Process

Figure 2

Sample search diary

Translation:

5/4/06: discussed with group members, decided to study the medium of instruction policy in Hong Kong. 8/4/06: I was assigned to seek relevant policy from the Internet. I have surfed on the Internet for an hour but could not find something relevant. Seek help from [a student in the group].

Figure 3

Feelings at beginning and end of search process 


\section{APPENDIX}

1. The subject and problem area of the project (專題的課題及研究範圍)

Describe briefly the subject and problem area of the project (簡單描述專題的課題及研 究範圍)

2. What do you know about the topic beforehand (開始專題前你對此題目的認識)
Much 很多 $\square$ Some 一些
Little 很少
Nothing 沒有認識

3. Use of information sources (使用資料)

Mark which sources you have been using in connection with your project until now with a number from 1-5 which signifies the importance of the source $(5=$ most important)

(以 1-5 顯示曾使用過的, 與專題有關的資料的重要性, $5=$ 最重要 )

Printed 印刷品 Group members 組員 teacher 老師

People outside the group 其他人

The library 圖書館

Web-pages 網址

OPACs 圖書館公共檢索系統

WiseNews 慧科剪報 none 沒有

Other types of databases, please note them down: 其他資料庫, 請說明:

4. Aim of use of information sources, (使用資料的目的)

To understand the topic / problem area 理解研究題目/問題

To define the topic/problem area 界定㸴究題目/問題

To explore on the topic / problem area 探索㸴究題目/問題

To formulate the focus 擬訂研究焦點

To get information supporting the focus 搜集支持研究焦點資料

Final information search 最後資料搜集

Other, please note them down: 其他，請說明：

5. Internet experience 使用互聯網經驗

1 year or less 少於 1 年 口 $\quad 2-3$ years 2-3 年口 4-5 years 4-5 年

more than 5 years 多於 5 年 $\square$ No 從沒有

6. Difficulties encountered

Mark the difficulties you have encountered in the research process until now with a number from 1-5, which signifies the level of difficulty (5=most difficult)

(硎習過程中碰到甚麼困難? 以 $1-5$ 顯示，5=最困難 )

No deep knowledge on the topic 硎究前對題目沒有認識

Do not understand the project requirement 不清楚研究題目要求

Hard to formulate the project focus 難以確定研究焦點

Do not know how to find relevant information 不知道如何找到相關的資料

Communication problems with group members 與組員溝通問題

Lack of time 時間不足 
Others, please note them down 其他, 請說明

Agreement statements

Mark with a number from 1-5 your agreement on the following statements

(你對以下句子的同意程度，以 1-5 顯示)

7. My understanding of the focus of the project is clear (我清楚了解專題的研究焦點)

Agreeing a lot Agreeing Almost Agreeing Agreeing a little

Disagreeing

非常同意 同意 大致同意 一點同意 不同意

$5 \square \quad 4 \square \quad 3 \square \quad 2 \square \quad 1 \square$

8. I'm motivated for working for working with the project (我有研究此專題的動力)

Agreeing a lot Agreeing Almost Agreeing Agreeing a little Disagreeing 非常同意同意 大致同意 一點同意 不同意

5 口 $\quad 4$ 口 3 口 $\quad 2$ 口 $\quad 1 \square$

9. I'm choosing my information sources primarily based on practical reasons (我基於實際的理由選擇資料)

Agreeing a lot Agreeing Almost Agreeing Agreeing a little

Disagreeing

非常同意 同意 大致同意 一點同意 不同意

$5 \square \quad 4 \square \quad 3 \square \quad 2 \square \quad 1 \square$

10. I find people more trustworthy than other information sources (我認爲他人意見比其 他資料可信)

Agreeing a lot Agreeing Almost Agreeing Agreeing a little

Disagreeing

非常同意 同意 大致同意 一點同意 不同意

$5 \square \quad 4 \square \quad 3 \square \quad 2 \square \quad 1 \square$

11. I find discussions with my teacher can help me formulate the focus of the project (與老師討論有助我確定研究的焦點)

Agreeing a lot Agreeing Almost Agreeing Agreeing a little

Disagreeing

非常同意 同意 大致同意 一點同意 不同意

5 口 $\quad 4 \square \quad 3 \square \quad 2 \square \quad 1 \square$

12. How do you communicate in the group (你與組員的聯絡方法)

Email 電郵 $\square \quad$ MSN/ICQ $\square \quad$ Meetings 會議

Telephone 電話 $\square \quad$ Others 其他 $\square$ (Please note them down 請說

明: )

13. How often are you in contact with some of all of the group members (for the project purpose) (你就此專題與組員聯絡的頻率/次數)

Daily 每天 $\square \quad$ Several times a week 一星期數次 $\square$

Weekly 每星期一次 $\square \quad$ Never 從不

14. Have you worked on you own before (你曾否做過個人專題報告?)

Yes 是 $\square \quad$ No 否 
15. If you have a chance to modify parts of the project, which do you prefer: individual base or group base? (假如你有機會修改本專題，你喜歡哪種形式：個人還是小 組?)

Individual base 個人 $\square \quad$ Group base 小組

16. How did you feel at the beginning of this project? (專題㸴習開始時, 你有何感 覺?)

Uncertain 不確定 $\square \quad$ Frustrated 挫折 $\square$ Confused 混亂 口

Excited 興奮 $\square$ Relieved 輕鬆 口 Satisfying 滿足

Other feelings, please note them here: 其他感覺, 請說明:

17. How do you feel now? (現在你有何感覺?)

Uncertain 不確定 $\square \quad$ Frustrated 挫折 $\square$ Confused 混亂 口

Excited 興奮 口 Relieved 輕鬆 口 Satisfying 滿足

Other feelings, please note them down: 其他感覺, 請說明:

18. Was there any transition of feelings during your information search process; for example, from uncertain to certain? (搜集專題資料的過程中，有沒有經歷情緒的 轉折點, 如由不確定轉爲確定?). If Yes, please note down when was the transition feelings (有, 請寫出什麼時候出現轉折點):

No.

19. Reflections / other comments? 反思或其他意見

Modified from Hyldegård (2006). 


\begin{tabular}{|c|c|c|c|c|c|c|}
\hline Stages & Task initiation & $\begin{array}{l}\text { Topic } \\
\text { selection }\end{array}$ & $\begin{array}{l}\text { Pre-focus } \\
\text { exploration }\end{array}$ & $\begin{array}{l}\text { Focus } \\
\text { formulation }\end{array}$ & $\begin{array}{l}\text { Information } \\
\text { collection }\end{array}$ & Search closure \\
\hline Feelings & uncertainty & optimism & confusion & clarity & $\begin{array}{l}\text { Sense of } \\
\text { direction / } \\
\text { confidence }\end{array}$ & $\begin{array}{l}\text { Relief / } \\
\text { satisfaction or } \\
\text { frustration }\end{array}$ \\
\hline Thoughts & General/vague & & & Narrower/clearer & $\begin{array}{l}\text { Increased } \\
\text { interest }\end{array}$ & Clearer/focused \\
\hline Actions & $\begin{array}{l}\text { Seeking } \\
\text { background } \\
\text { information }\end{array}$ & & $\begin{array}{l}\text { Seeking } \\
\text { relevant } \\
\text { information }\end{array}$ & & $\begin{array}{l}\text { Seeking } \\
\text { relevant or } \\
\text { focused } \\
\text { information }\end{array}$ & \\
\hline
\end{tabular}




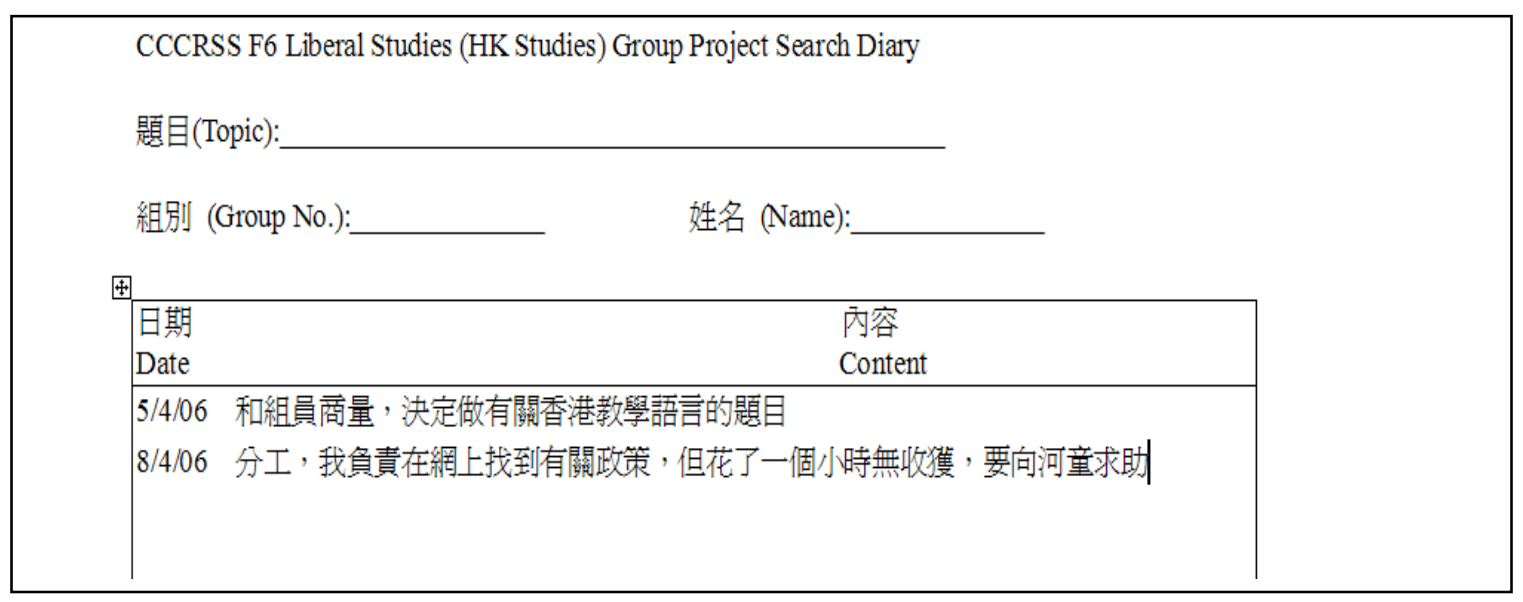




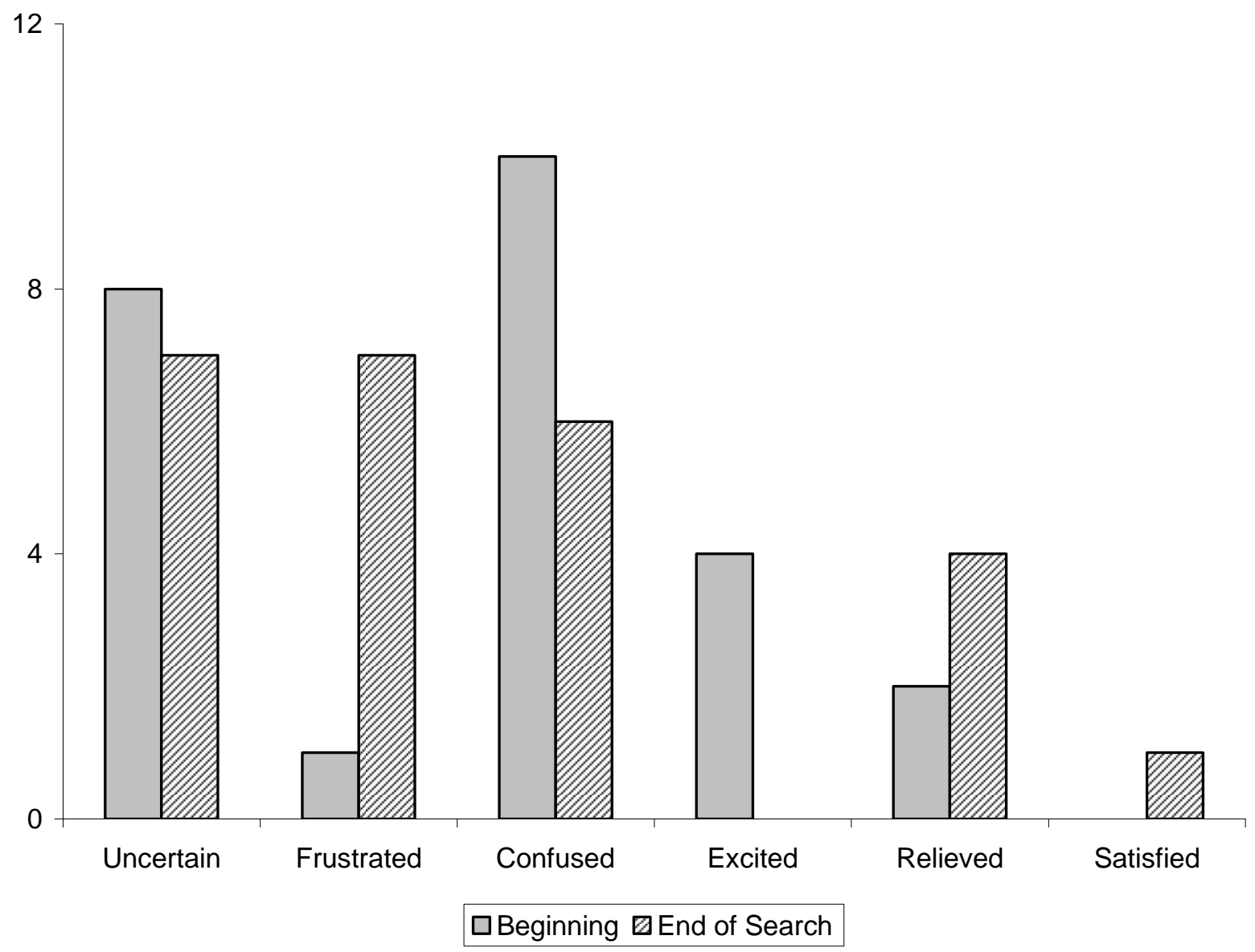




\begin{tabular}{lcccc}
\hline Type of Source & \multicolumn{2}{c}{ Students Who Used Source } & \multicolumn{2}{c}{ Importance of Source } \\
& \multicolumn{2}{c}{$n=14$} & & $n=18$ \\
& $f$ & $\%$ & & $S D$ \\
Printed & 7 & 50 & 1.64 & 0.92 \\
(non-library) & & & & \\
Group members & 13 & 92 & 3.35 & 1.00 \\
Teacher & 9 & 64 & 3.23 & 1.01 \\
People outside & 4 & 28 & 2.38 & 1.41 \\
group & & & & \\
Library & 4 & 28 & 2.88 & 1.55 \\
Web pages & 14 & 100 & 4.22 & 0.87 \\
OPAC & - & - & 2.75 & 1.26 \\
WiseNews & 12 & 85 & 3.84 & 1.15 \\
database & & & & \\
\hline
\end{tabular}




\begin{tabular}{|c|c|c|c|c|c|}
\hline & Email & MSN/ICQ & Meetings & Telephone & Others \\
\hline Group 1 & & 3 & 3 & & \\
\hline Group 2 & & 3 & 3 & & \\
\hline Group 3 & & 2 & & 2 & \\
\hline Group 4 & 1 & 1 & 1 & 2 & 1 (ftp) \\
\hline Group 5 & & 1 & 1 & 3 & \\
\hline Group 6 & & 3 & 1 & 2 & \\
\hline Total & 1 & 13 & 9 & 10 & 1 \\
\hline
\end{tabular}




\begin{tabular}{lccc}
\hline Group & Understanding of Focus & Motivation Score & Teacher's Group Assessment \\
\hline 1 & $2,2,2$ & $2,2,2$ & 3 \\
2 & $3,4,4$ & $4,4,4$ & 4 \\
3 & 4,3 & 3,4 & 2 \\
4 & 1,3 & 4,4 & 3 \\
5 & $3,2,2$ & $3,2,2$ & 2 \\
\hline
\end{tabular}

